Article

\title{
The Effects of Endogenous Non-Peptide Molecule Isatin and Hydrogen Peroxide on Proteomic Profiling of Rat Brain Amyloid- $\beta$ Binding Proteins: Relevance to Alzheimer's Disease?
}

\author{
Alexei E. Medvedev ${ }^{1,2, *}$, Olga A. Buneeva ${ }^{1}$, Arthur T. Kopylov ${ }^{1}$, Oksana V. Gnedenko ${ }^{1}$, \\ Marina V. Medvedeva ${ }^{3}$, Sergey A. Kozin ${ }^{2}$, Alexis S. Ivanov ${ }^{1}$, Victor G. Zgoda ${ }^{1}$ \\ and Alexander A. Makarov ${ }^{2}$
}

1 Department of Proteomic Research and Mass Spectrometry, Institute of Biomedical Chemistry, 10 Pogodinskaya Street, Moscow 119121, Russia; E-Mails: olbun@yandex.ru (O.A.B.); a.t.kopylov@gmail.com (A.T.K.); oksana_gnedenko@pochta.ru (O.V.G.); asi@icnet.ru (A.S.I.); vic@ibmh.msk.su (V.G.Z.)

2 Engelhardt Institute of Molecular Biology, Russian Academy of Sciences, Moscow 119991, Russia; E-Mails: kozinsa@gmail.com (S.A.K.); aamakarov@eimb.ru (A.A.M.)

3 School of Biology, Lomonosov Moscow State University, Moscow 119191, Russia; E-Mail: marmed64@yandex.ru

* Author to whom correspondence should be addressed; E-Mail: professor57@yandex.ru; Tel.: +7-499-245-05-09; Fax: +7-499-245-08-57.

Academic Editor: Charles A. Collyer

Received: 14 October 2014 / Accepted: 16 December 2014 / Published: 29 December 2014

\begin{abstract}
The amyloid- $\beta$ peptide is considered as a key player in the development and progression of Alzheimer's disease (AD). Although good evidence exists that amyloid- $\beta$ accumulates inside cells, intracellular brain amyloid-binding proteins remain poorly characterized. Proteomic profiling of rat brain homogenates, performed in this study, resulted in identification of 89 individual intracellular amyloid-binding proteins, and approximately $25 \%$ of them were proteins that we had previously identified as specifically binding to isatin, an endogenous neuroprotector molecule. A significant proportion of the amyloid-binding proteins (more than 30\%) are differentially expressed or altered/oxidatively modified in $\mathrm{AD}$ patients. Incubation of brain homogenates with $70 \mu \mathrm{M}$ hydrogen peroxide significantly influenced the profile of amyloid- $\beta$ binding proteins and $0.1 \mathrm{mM}$ isatin decreased the number of identified amyloid- $\beta$ binding proteins
\end{abstract}


both in control and hydrogen peroxide treated brain homogenates. The effects of hydrogen peroxide and isatin have been confirmed in optical biosensor experiments with purified glyceraldehyde-3-phosphate dehydrogenase, one of the known crucial amyloid- $\beta$ binding proteins (also identified in this study). Data obtained suggest that isatin protects crucial intracellular protein targets against amyloid binding, and possibly favors intracellular degradation of this protein via preventing formation of amyloid- $\beta$ oligomers described in the literature for some isatin derivatives.

Keywords: amyloid- $\beta$; amyloid- $\beta$ binding proteins; proteomic profiling; rat brain; isatin; oxidative stress

\section{Introduction}

The amyloid- $\beta$ peptide $\mathbf{1 - 4 2}$ formed during proteolytic processing of the amyloid precursor protein (APP) is considered as a key player in the development or progression of Alzheimer's disease (AD) and other pathologies associated with the formation of protein aggregates in the central nervous system ([1-8] and many others). Although much attention is paid to formation of extracellular amyloid plaques and protein aggregates as well as to corresponding mechanisms of their toxicity, good evidence exists that intracellular amyloid- $\beta$ can accumulate intraneuronally and contribute to disease progression [4,9-15]. Results of experiments on transgenic mice indicate that the intraneuronal amyloid- $\beta$ accumulation precedes plaque formation [16]. This suggests the importance of amyloid- $\beta$ interaction with particular intracellular targets. Indeed, interaction of amyloid- $\beta$ with intracellular catalase caused inactivation of this enzyme and accumulation of hydrogen peroxide inside cells [17]. This implies that oxidative stress induced in the cells exposed to amyloid- $\beta$ may be (at least partially) associated with reduced degradation of intracellular hydrogen peroxide [17].

In the cell, amyloid-beta was found in different intracellular compartments [4]. The latter suggests the possibility of amyloid interaction with a broad range of proteins, which may be thus denominated as amyloid- $\beta$ binding proteins. Although there are reports on the interaction of amyloid- $\beta$ peptide with various intracellular proteins (e.g., [17,18]) and development of protocols for affinity isolation of amyloid- $\beta$ binding proteins [19], the affinity based proteomic profiling of brain proteins interacting with immobilized amyloid- $\beta$ has not been performed yet. Some previous studies revealed several important intracellular proteins involved in direct interaction with amyloid- $\beta$. These include glyceraldehydes-3-phosphate dehydrogenase (EC 1.2.1.12) (GAPDH) [20-22]. This glycolytic enzyme, a classical glycolytic redox sensitive enzyme, exhibits various non-glycolytic functions that are considered to be especially important for progression of various neurodegenerative diseases, particularly AD [23]. GAPDH is considered as a potential target for neuroprotective drugs. GAPDH interacts with isatin, an endogenous indole exhibiting properties of an endogenous neuroprotective molecule [24-27]. Previous studies have also shown that a significant proportion of rat (or mouse) brain proteins specifically interacted with isatin [28-30], are oxidatively modified in various AD models [11,31-33]. This suggests the existence of a possible interrelationship between capacities of at least some redox sensitive brain intracellular proteins to interact with both amyloid-beta and isatin. 
Thus, in this study we have investigated proteomic profiles of beta-amyloid binding proteins of rat brain and their changes induced by hydrogen peroxide and/or isatin. The results of proteomic profiling have been validated in a surface plasmon resonance (SPR) based study with purified glyceraldehyde-3-phosphate dehydrogenase.

Data obtained suggest that interaction between amyloid-beta and its crucial intracellular targets may be influenced by (non-peptide) small organic molecules such as isatin and this opens new possibilities in pharmacological prevention of amyloid-beta toxicity.

\section{Results}

\subsection{Proteomic Profiling of Amyloid-Binding Proteins of Intact Rat Brain Homogenate}

Loading of cleared Triton X-100 lysates of whole brain homogenate onto the affinity sorbent, amyloid-beta-Affi-Gel 10, followed by wash with $50 \mathrm{mM}$ potassium phosphate buffer, $\mathrm{pH} 7.4$, resulted in adsorption of $10.4 \%$ of the total protein applied. The control Affi-Gel 10 lacking the affinity ligand bound not more than $4 \%$ of the total protein applied. This suggests that about $6 \%$ of homogenate proteins specifically bound to the affinity sorbent. Subsequent elution of adsorbed proteins followed by their proteomic analysis resulted in identification of at least 89 individual intracellular $\beta$-amyloid binding proteins specifically bound to the affinity sorbent (Table S1). They have different intracellular localization and functionally, the identified proteins can be subdivided into the following groups (Figure 1): (i) Energy generation and carbohydrate metabolism; (ii) Cytoskeleton formation and exocytosis/trafficking; (iii) Regulation of gene expression, cell division and differentiation; (iv) Signal transduction and regulation of enzyme activity; (v) Antioxidant and protection proteins/enzymes; (vi) Metabolism of amino acids and other nitrogenous compounds; and (vii) Lipid metabolism. It is particularly significant that metabolic consequences of amyloid-beta interaction with some of these proteins (e.g., catalase, cytochrome oxidase) have already been documented and analyzed in the literature [17,18].

In accordance with our previous studies [28-30], among proteins non-specifically bound to the ligand-free control sorbent, we detected only highly abundant rat brain proteins [34]: The cytoskeletal keratins $(10,1,6 \mathrm{~A}, 14)$, and the mitochondrial precursor of $\beta$-subunit of ATP synthase. Interestingly, most of these proteins bound non-specifically to both Sepharose [29,30] and Affi-Gel. Thirty of eighty nine amyloid-binding proteins (more than 30\%) were found to be oxidatively modified/altered either in brains of $\mathrm{AD}$ patients or in different experimental models of this disease (Table 1).

Twenty three of eighty nine amyloid-binding proteins (more than 25\%) have been identified earlier [28-30] as proteins specifically bound to isatin (indole-2,3-dione), an endogenous indole which has a distinct and discontinuous distribution in the brain and in other mammalian tissues and body fluids $[24,25,27]$. Some of them undergo oxidative modification in AD (Table 1).

One of these oxidatively modified proteins which also interact with isatin is glyceraldehyde-3-phosphate dehydrogenase (GAPDH) [26]. 


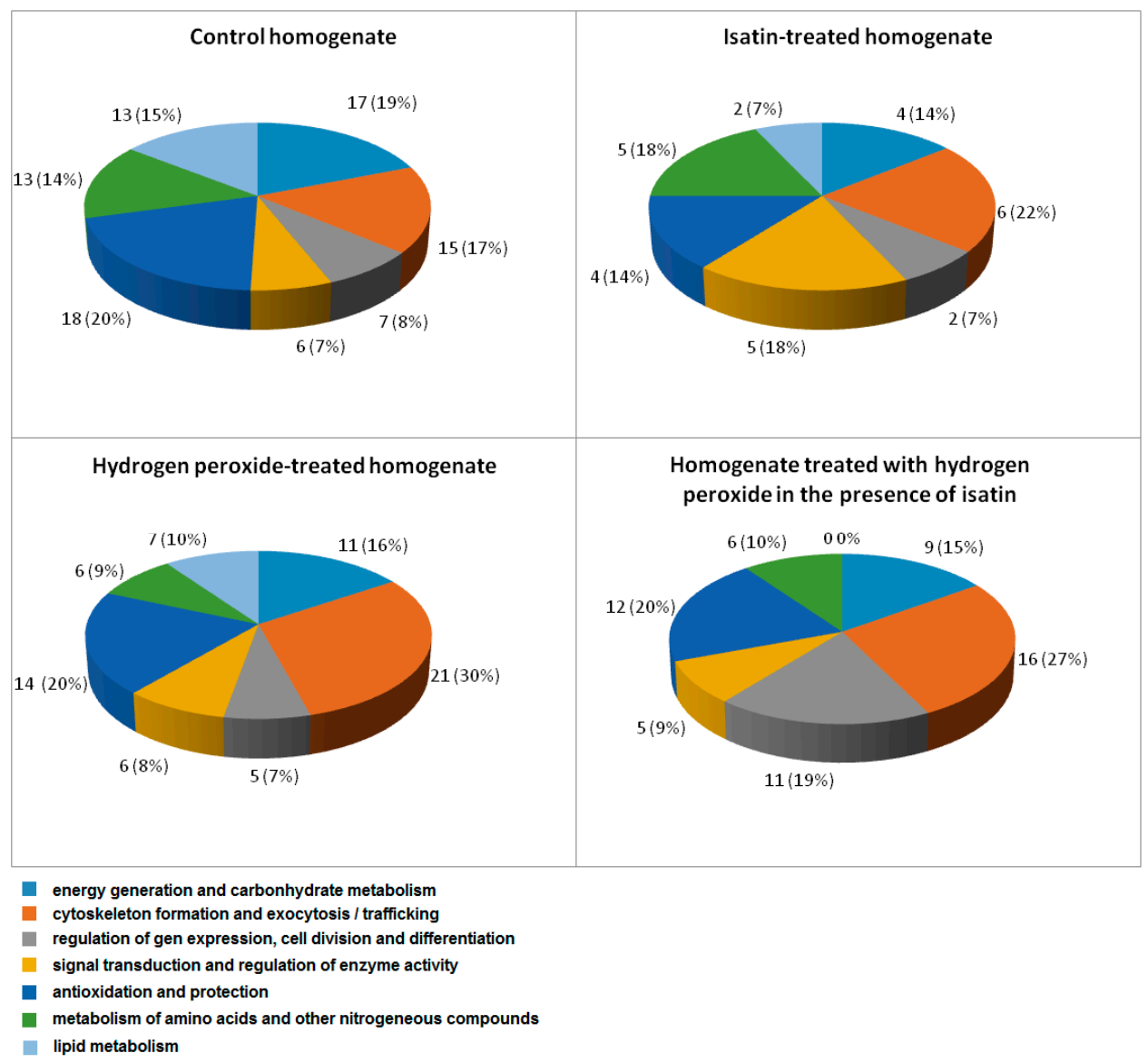

Figure 1. Subdivision of amyloid-binding proteins identified in brain homogenates by their functions: Numbers indicate total number of proteins in each group and numbers in parentheses show the percentage of the total number of identified proteins.

Table 1. Amyloid-binding proteins altered or oxidatively modified in Alzheimer's disease and related pathologies and their experimental models.

\begin{tabular}{cccc}
\hline No. & Protein Name & $\begin{array}{c}\text { Changes in Pathology } \\
\text { or Experimental Model }\end{array}$ & Reference \\
\hline 1 & Pyruvate kinase isozymes M1/M2 & OM, I & {$[11,33,35]$} \\
2 & Actin, cytoplasmic 1 & OM, D & {$[36,37]$} \\
3 & Heat shock cognate 71 kDa protein & OM & {$[38]$} \\
4 & ATP synthase subunit $\beta$, mitochondrial & I & {$[39]$} \\
5 & Alpha-enolase & OM, I, AALS & {$[33,35,40,41]$} \\
6 & Myelin basic protein S & OM & {$[11]$} \\
7 & Glutathione S-transferase $\alpha-2$ & OM & {$[11]$} \\
8 & Dihydropyrimidinase-related protein 2 & OM, I, D, AALS & {$[11,40-42]$} \\
9 & 60 kDa Heat shock protein, mitochondrial & D & {$[39]$} \\
10 & Glyceraldehyde-3-phosphate dehydrogenase & OM & {$[11,33]$} \\
11 & Fructose-bisphosphate aldolase A & OM & {$[33]$} \\
12 & ATP synthase subunit $\alpha$, mitochondrial & D & {$[39]$} \\
13 & Endoplasmin & OM & {$[33]$} \\
14 & Peroxiredoxin-1 & I & {$[43]$} \\
15 & Stress-70 protein, mitochondrial & I & {$[44-46]$} \\
\hline
\end{tabular}


Table 1. Cont.

\begin{tabular}{cccc}
\hline No. & Protein Name & $\begin{array}{c}\text { Changes in Pathology } \\
\text { or Experimental Model }\end{array}$ & Reference \\
\hline 16 & Retinol-binding protein 4 OS & D & {$[47]$} \\
17 & 78 kDa Glucose-regulated protein & OM, AALS & {$[33,41]$} \\
18 & Peroxiredoxin-2 & OM, I & {$[33,43,48]$} \\
19 & Glutamine synthetase & OM, I & {$[11,40]$} \\
20 & Glutathione $S$-transferase P OS & OM & {$[11]$} \\
21 & Glutamate dehydrogenase 1, mitochondrial & OM, AALS & {$[33,41]$} \\
22 & Heat shock protein HSP 90- $\alpha$ & I & {$[49]$} \\
23 & Spectrin $\alpha$ chain, non-erythrocytic 1 & OM & {$[11]$} \\
24 & Phosphoglucomutase-1 & OM & {$[32]$} \\
25 & Synaptotagmin-1 & D & {$[44,50]$} \\
26 & Phosphatidylethanolamine-binding protein & I & {$[51]$} \\
27 & Calmodulin & D, AALS & {$[41,52]$} \\
28 & Protein disulfide-isomerase & AALS & {$[41]$} \\
29 & Superoxide dismutase [Mn] & OM & {$[53]$} \\
30 & Tubulin $\alpha-1$ A chain & OM & {$[32]$} \\
\hline
\end{tabular}

I-Increased, D—Decreased, OM—Oxidatively modified, AALS—Altered affinity to lectin sorbents.

\subsection{The Effects of Hydrogen Peroxide and Isatin on the Interaction of Glyceraldehyde-3-phosphate}

\section{Dehydrogenase (GAPDH) with Immobilized Amyloid- $\beta$ and Actin}

The injection of highly purified GAPDH to the biosensor flow cell with immobilized amyloid- $\beta$ caused a clear concentration-dependent response of the biosensor signal (Figure 2). Its magnitude and shape differed both in the case of intact and oxidized GAPDH and also in the case of the same manipulations with the biosensor flow cell containing immobilized actin, used as a control. This obviously reflects different modes of intact and oxidized GAPDH interaction with immobilized amyloid- $\beta$ and actin. In order to elucidate affinity of these interactions we have determined $K_{\mathrm{d}}$ values for the complexes of intact and oxidized GAPDH with immobilized amyloid- $\beta$ and actin.

The calculated $K_{\mathrm{d}}$ value for the GAPDH amyloid- $\beta$ complex of $0.22 \pm 0.02 \mu \mathrm{M}$ was in the range of $K_{\mathrm{d}}$ values for GAPDH complexes with actin reported in the literature [54]. In our experimental conditions GAPDH affinity to amyloid beta was even higher than to actin (the $K_{\mathrm{d}}$ value of $1.22 \pm 0.2 \mu \mathrm{M}$, $p<0.01$ versus the $K_{\mathrm{d}}$ value for GAPDH binding to amyloid- $\beta$ ) (Figure 2). Addition of the GAPDH cofactor, NAD (oxidized nicotineamide adenine dinucleotide) (0.01-5 mM), did not influence the behavior of the biosensor response implying lack of any influence of NAD (at least at physiological concentrations) on GAPDH binding to amyloid- $\beta$ (data not shown), while $0.1 \mathrm{mM}$ isatin decreased this binding and increased the $K_{\mathrm{d}}$ values (Figure 3 ).

In accordance with previous studies [54], GAPDH oxidation with $70 \mu \mathrm{M} \mathrm{H}_{2} \mathrm{O}_{2}$ was accompanied by a dramatic (more than 15-fold) decrease in catalytic activity of this enzyme (from 111 to $6 \mu \mathrm{mol} / \mathrm{min}$ per mg of protein) and also by a dramatic (more than 15 -fold) increase in the $K_{\mathrm{d}}$ value for the enzyme interaction with amyloid- $\beta$ (Figure 3A). This effect was specific for GAPDH interaction with amyloid- $\beta$ as neither oxidation nor isatin significantly influenced GAPDH interaction with actin, 
one of the major cytoskeleton components (Figure 3B). This suggests that oxidative stress and isatin could influence profiles of amyloid-binding proteins in the brain.
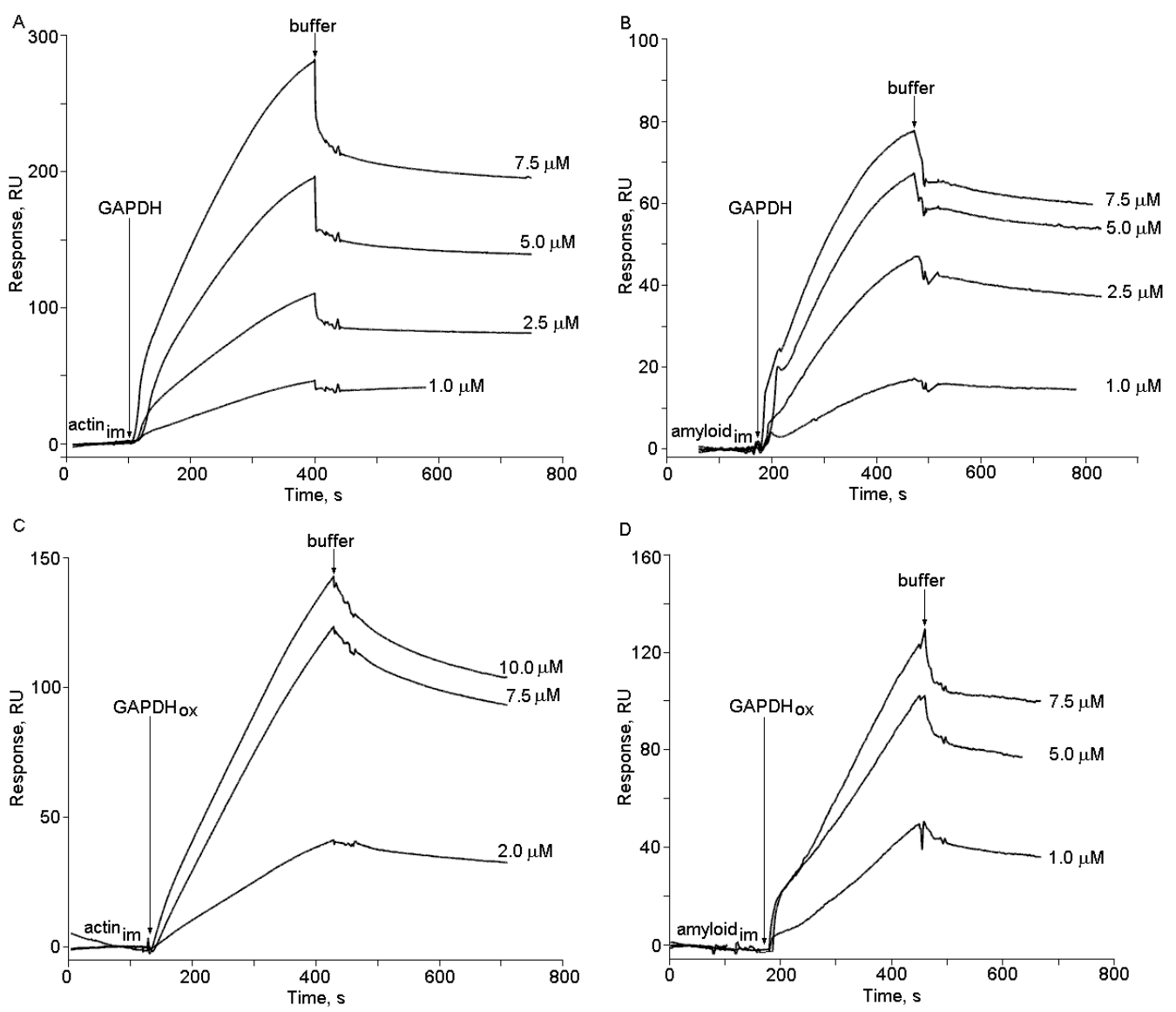

Figure 2. Sensograms of binding of native $(\mathbf{A}, \mathbf{B})$ and oxidized $(\mathbf{C}, \mathbf{D})$ glyceraldehyde-3phosphate dehydrogenase $(\mathrm{GAPDH})$ to immobilized actin $(\mathbf{A}, \mathbf{C})$ and amyloid- $\beta(\mathbf{B}, \mathbf{D})$. Arrows indicate onset of injection.

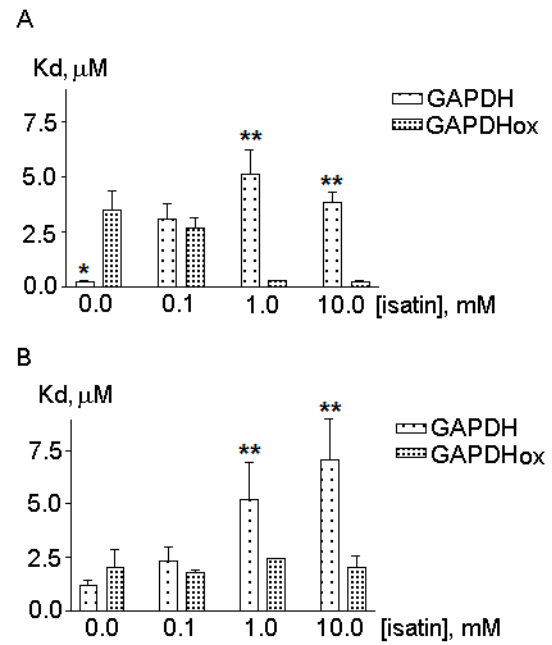

Figure 3. The effect of GAPDH oxidation on $K$ d values for GAPDH interaction with immobilized actin (A) and amyloid-beta (B). Data represent mean \pm SEM from 3-5 independent experiments. Asterisks show statistically significant differences in $K_{\mathrm{d}}$ values for intact and oxidized GAPDH $(* p<0.05 ; * * p<0.01)$ evaluated by paired Student's $t$-test. 


\subsection{Effects of Hydrogen Peroxide and Isatin on Proteomic Profiles of Rat Brain Amyloid-Binding Proteins}

Indeed, the presence of $0.1 \mathrm{mM}$ isatin significantly decreased the number of proteins specifically bound to amyloid- $\beta$ to 28 (Table S2); however, only half of them were common with the group of amyloid-binding proteins of intact brain homogenate.

Induction of oxidative stress by incubating rat brain homogenates with hydrogen peroxide significantly influenced both the total number of amyloid-binding proteins specifically bound to the affinity sorbent and the profile of identified individual proteins (Table S3). The total number of identified proteins slightly decreased $(n=70)$ and comparison of the proteomic profiles of control and hydrogen peroxide treated brain homogenates revealed 50 common proteins.

Incubation of rat brain homogenate with hydrogen peroxide and isatin caused a further decrease in the total number of brain proteins bound to amyloid- $\beta$ as compared with hydrogen peroxide treated brain homogenate (59 versus 70) (Table S4). However, the number of proteins coincided in brain homogenates treated with hydrogen peroxide in the absence and in the presence of $0.1 \mathrm{mM}$ isatin were just 23, which is significantly less as compared to control and hydrogen peroxide treated homogenates (Figure 4).

In this context, it should be noted that among four groups of rat brain preparations, only six proteins coincided (Table 2); and only two of them, stress-70 protein and endoplasmin, are known to be oxidized in neurodegenerative diseases in patients and/or corresponding experimental models in animals.

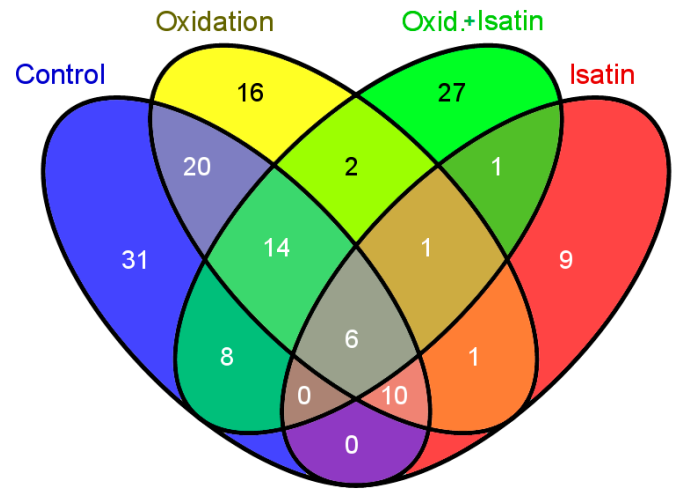

Figure 4. A Venn diagram illustrating the groups comprising the total number of coincided amyloid-binding proteins: control, oxidation, isatin, oxidation in the presence of isatin. Numbers of coincided proteins are shown within intersection areas and numbers outside intersections show proteins specific for each group.

Table 2. Common amyloid-binding proteins for all experimental groups.

\begin{tabular}{cccc}
\hline No. & Protein Name & $\begin{array}{c}\text { Intracellular } \\
\text { Localization * }\end{array}$ & $\begin{array}{c}\text { Oxidatively } \\
\text { Modified/Altered in AD Brain } \\
\text { and Different AD Models ** }\end{array}$ \\
\hline 1 & $\begin{array}{c}\text { Carbamoyl-phosphate } \\
\text { synthase [ammonia], mitochondrial }\end{array}$ & $\mathrm{M}$ & No \\
2 & $\begin{array}{c}\text { Betaine-homocysteine } S \text {-methyltransferase } 1 \\
3\end{array}$ & C & No \\
Fructose-bisphosphate aldolase B & C, L, N, ER, CM & No \\
\hline
\end{tabular}


Table 2. Cont.

\begin{tabular}{lccc}
\hline No. & Protein Name & $\begin{array}{c}\text { Intracellular } \\
\text { Localization * }\end{array}$ & $\begin{array}{c}\text { Oxidatively } \\
\text { Modified/Altered in AD Brain } \\
\text { and Different AD Models ** }\end{array}$ \\
\hline 4 & Endoplasmin ** & ER & Yes \\
5 & Stress-70 protein, mitochondrial ** & M & No \\
6 & Keratin, type II cytoskeletal 73 & C & Nes \\
\hline & $*$ Designation of intracellular localization is the same as in other tables; ** See Table 1 for details and \\
&
\end{tabular}

Thus, it appears that the repertoire of amyloid-beta binding proteins is influenced not only by oxidative stress but also by the presence of low molecular weight substances, which are obviously involved in the regulation of amyloid- $\beta$ interaction with various subcellular proteins.

\section{Discussion}

Results of the present study indicate that a large group of intracellular brain proteins can specifically interact with amyloid- $\beta$. They belong to different intracellular compartments and different functional groups (Tables S1-S4 and Figure 1).

(Patho)physiological importance of the amyloid- $\beta$ interaction with some of the identified proteins has been already demonstrated by other authors. For example, catalase inactivation by binding to amyloid- $\beta$ [17] may explain intracellular accumulation of hydrogen peroxide followed by subsequent development of oxidative stress described in numerous studies. Some cytosolic proteins identified in this study as the amyloid- $\beta$ binding proteins demonstrate reduced solubility in a transgenic mouse model of Alzheimer-type amyloidosis [16].

More than $30 \%$ of amyloid- $\beta$ binding proteins are oxidized in AD brain and different AD models identified (Table 1). One of these oxidatively-modified proteins is GAPDH. This protein attracts special interest due to its multiple roles related to neurodegeneration and AD [23,55-58].

Being a classical glycolytic enzyme, GAPDH also exhibits various (patho)biological activities (see for review [23,40]) and is a putative target for neuroprotective drugs [26,59,60]. This redox sensitive enzyme can interact with both cytoskeleton components (e.g., actin) [61,62] and aggregate-prone proteins (e.g., amyloid- $\beta$ ) involved in the development and progression of some neurodegenerative disorders such as $\mathrm{AD}[23,57]$. Several studies have demonstrated localization of GAPDH in plaques $[55,56]$. Binding of this enzyme to the recombinant cytoplasmic domain of $\beta$-amyloid precursor protein [20] and immobilized amyloid- $\beta$ as the affinity ligand [21,63] have shown direct binding of brain GAPDH to both fibrillar and nonfibrillar forms of amyloid-beta peptide 1-42. Although GAPDH also bound to fibrillar crystalline (used as negative control) its coprecipitation with amyloid- $\beta$ occurred more effectively [21]. Our results of surface plasmon resonance (SPR)-based studies indicate that GAPDH directly binds not only to immobilized amyloid- $\beta$ but also to actin; however, it also exhibits higher affinity to amyloid- $\beta$ than to actin. Since physiological concentrations of NAD (cofactor of GADPH) have no influence on GAPDH interaction with amyloid- $\beta$, it appears that this interaction does not depend on catalytic properties of this enzyme. 
It should be noted that GAPDH represents a good model protein for analysis of interaction of intracellular brain proteins with amyloid- $\beta$ and the effect of oxidative stress and pharmacologically-relevant compounds on this interaction.

Oxidation of purified GAPDH caused a dramatic decrease in its affinity to amyloid- $\beta$ as evidenced by a more than 15 -fold increase in the $K_{\mathrm{d}}$ value (Figure $3 \mathrm{~B}$ ) for the complex oxidized GADPH immobilized amyloid- $\beta$. GAPDH was identified among amyloid-binding proteins after pretreatment of brain homogenate with hydrogen peroxide but it was not detected in the case of intact homogenate pretreated with $0.1 \mathrm{mM}$ isatin (Tables $\mathrm{S} 1$ and 3). In this context, it is reasonable to suggest that the $K_{\mathrm{d}}$ values ranging from 2.5 to $3.5 \mu \mathrm{M}$ (Figure 3) represent the lowest affinity limit, where binding of (oxidized) brain homogenate GAPDH to immobilized amyloid- $\beta$ was still possible but the presence of $0.1 \mathrm{mM}$ isatin prevented this binding.

As proved by both optical biosensor experiments and proteomic profiling, the presence of $0.1 \mathrm{mM}$ isatin significantly decreased affinity of highly purified GAPDH to amyloid- $\beta$ immobilized (Figure 3B) on the surface of the biosensor chip and also prevented binding of brain homogenate GAPDH to the affinity sorbent with immobilized amyloid- $\beta$ as the affinity ligand.

Thus, different interaction behaviors of intact and oxidized purified GAPDH towards amyloid- $\beta$ immobilized on the biosensor chip is generally consistent with changes in the proteomic profiles of intact and oxidized brain homogenates and the influence of isatin on these protein-amyloid beta interactions.

Isatin is an endogenous indole widely distributed in mammalian brain, peripheral tissues and body fluids [24,25,27]. Its physiological concentrations in blood can exceed $1 \mu \mathrm{M}[64,65]$. Although basal tissue concentrations usually vary from 0.1 to $1 \mu \mathrm{M}$, in some tissues much higher levels of isatin (40-70 $\mu \mathrm{M})$ may also occur [27]. It interacts with all known biological targets in a readily reversible manner [24,25,27,29] and demonstration of its in vivo interaction with certain biological targets requires employment of special methodological approaches (e.g., [66]). Some experimental evidence exists that isatin may influence interaction of isatin binding proteins with cytoskeletal structures, important for both manifestation and attenuation of neurodegenerative disorders [29].

Mechanism(s), by which isatin decreases the number of proteins bound to the amyloid- $\beta$ affinity sorbent, still needs clarification. Our results of model experiments with amyloid- $\beta$ immobilized on the optical biosensor cuvette and (oxidized) GAPDH suggest direct interaction between isatin and amyloid-binding proteins. It appears that isatin competes with amyloid- $\beta$ for binding to protein targets. By analogy with hydrogen-peroxide induced changes in GAPDH sensitivity to isatin (Figure 2B,C) we suggest that oxidative stress influences protein affinity to isatin and therefore the repertoire of amyloid binding proteins.

Thus, results of our proteomic study indicate that not only oxidative stress in vitro but also such non-peptide endogenous compounds as isatin significantly influence the repertoire of brain amyloid-beta binding proteins. The latter suggests that the interaction of amyloid-beta with particular intracellular proteins may be regulated not only by amyloid beta accumulation in various intracellular organelles, and by their redox status, but also by concentrations of endogenous or exogenously administered compounds influencing amyloid- $\beta$ protein interactions. In this context, it is especially interesting in the present study that in the presence of $0.1 \mathrm{mM}$ isatin only $10 \%$ of brain proteins detected coincided with the proteins recently detected as the detergent-insoluble proteins identified 
in forebrains of the APPswe/PS1dE9 (line 85) transgenic mice [16]; in the absence of isatin the proportion of coincided proteins exceeded $30 \%$.

The isatin core has been used in the design of various compounds acting as inhibitors of apoptosis, anticonvulsants, and anxiolytics etc. [25,67] and administration of isatin improves symptoms of experimental Parkinsonism [68,69]. Studies with $\left[{ }^{3} \mathrm{H}\right]$ isatin revealed high density of isatin binding in hippocampus, and cortex $[28,70,71]$, i.e., the brain regions affected by amyloid- $\beta$ deposition in various models of $\mathrm{AD}$. Thus, it appears that the identity of a significant proportion of isatinand amyloid-binding proteins may have certain biomedical importance, and isatin itself, or its numerous analogues tested in many laboratories for different purposes [27,67,72,73], may be a useful tool for studies of the interaction of amyloid- $\beta$ and its intracellular targets and possibly as pharmacologically relevant compounds attenuating progression of $\mathrm{AD}$ in various experimental models. In this context, it is especially interesting that some recently synthesized isatin-3-arylhydrazones act as rather effective inhibitors of amyloid- $\beta$ aggregation in model systems [74], while some other isatin derivatives are effective inhibitors of transthyretin fibrillogenesis related to (senile) amyloidosis [75].

Taking into consideration data on the inhibition of aggregation of amyloidogenic proteins by isatin-based compounds, it is reasonable to suggest that endogenous isatin may be an effective neuroprotector at the very beginning of AD. Preventing interaction of amyloid- $\beta$ with crucial intracellular targets (e.g., catalase, GAPDH, $\alpha$-enolase etc.) isatin promotes their physiological functioning, while maintaining amyloid- $\beta$ in the monomeric form isatin favors its intracellular degradation (Figure 5).

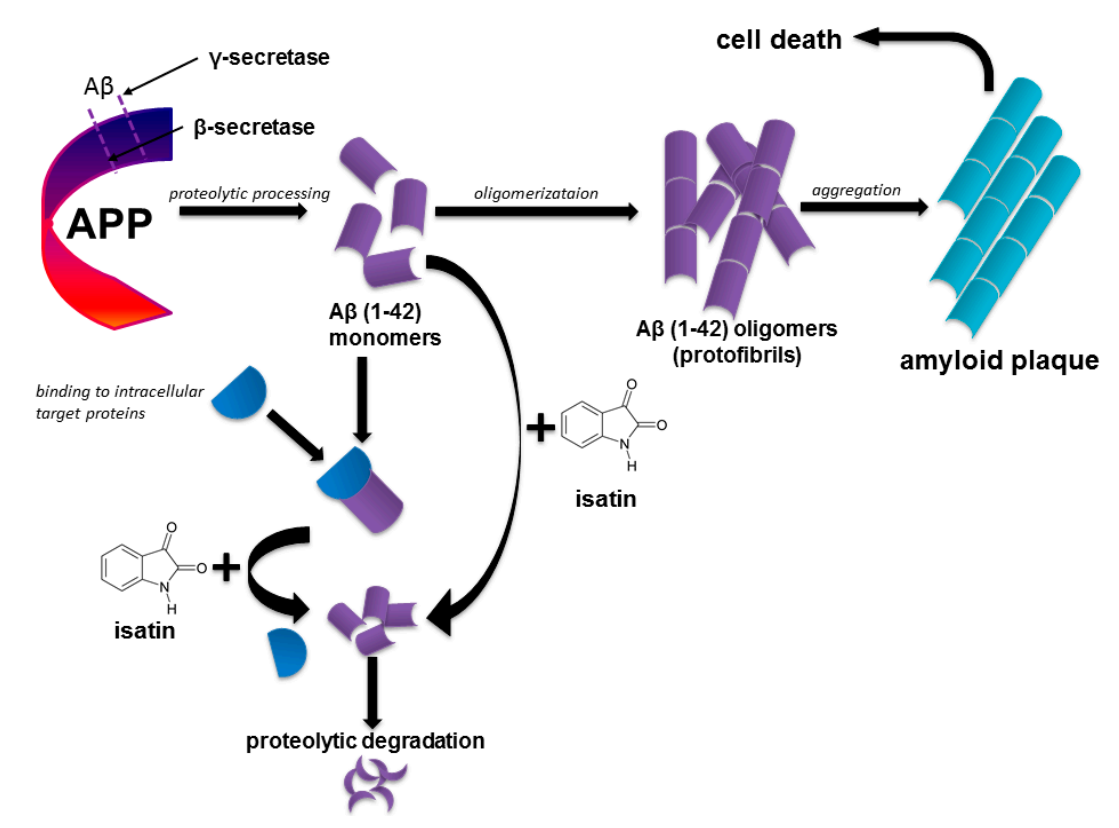

Figure 5. Proposed mechanism of isatin action in prevention of early molecular events leading to development of Alzheimer's disease.

The proposed scenario does not rule out other mechanisms involving direct amyloid- $\beta$ interaction with its intracellular targets. By analogy with amyloid-beta induced inactivation of catalase [17], it is possible that amyloid- $\beta$ binding to GAPDH may contribute to energy deficit and impairments in fast axonal transport associated with inhibition/inactivation of this enzyme [76]. 


\section{Experimental Section}

\subsection{Materials}

Acetic acid (sodium salt), boric acid, formic acid, sodium tetraborate, and sodium hydroxide were from Acros Organics (Geel, Belgium). Affi-Gel 10 was purchased from BioRad (Hercules, CA, USA).

Reagents for the Biacore biosensor were obtained from GE Healthcare (Piscataway, NJ, USA). These included HBS-EP buffer (150 mM NaCl, 3 mM EDTA, 0.005\% surfactant P20, $10 \mathrm{mM}$ HEPES, $\mathrm{pH}$ 7.4); $10 \mathrm{mM}$ acetate buffer, $\mathrm{pH} 4.0$; amine coupling reagents kit, containing 1-ethyl-3-(3dimethylaminopropyl) carbodiimide hydrochloride (EDC), $N$-hydroxysuccinimide (NHS) and $1 \mathrm{M}$ ethanolamine- $\mathrm{HCl}, \mathrm{pH} 8.5$.

All other materials and chemicals including the human amyloid- $\beta$ protein fragment (1-42) were from Sigma-Aldrich (St. Louis, MO, USA).

Rabbit muscle GAPDH was purified by the method of Scopes and Stoter [77]. The resulting enzyme preparations (specific activity $110-170 \mu \mathrm{mol} / \mathrm{min}$ per $\mathrm{mg}$ of protein as evaluated in the reaction of 3-phosphoglycerate reduction by $\mathrm{NADH}$ (reduced nicotinamide adenine dinucleotide) showed one band during electrophoresis in the Laemmli system. Before use, the purified enzyme was kept as an ammonium sulfate suspension at $+4{ }^{\circ} \mathrm{C}$ for not more than two weeks.

\subsection{Animals, Brain Homogenate Preparation and Incubations}

Male albino rats ( $n=24,200-250 \mathrm{~g}$ ) obtained from the Stolbovaya nursery (Russian Academy of Medical Sciences) were used in the experiments performed at least one week after their arrival from the nursery. Animals received a standard laboratory chow and water ad libitum and their decapitation was performed between 11.00 and $13.00 \mathrm{~h}$ under light ether anesthesia. All procedures conform to the Russian version of the Guide for the Care and Use of Laboratory Animals (Washington, 1996) and have been approved by the Animal Care and Use Committee of the Orekhovich Institute of Biomedical Chemistry issued on 16 June 2014 (identification number: EC3318-2014.2-IBMC).

The brains were immediately dissected and homogenized at a low speed in $0.05 \mathrm{M}$ potassium-phosphate buffer, pH $7.4(1: 3, w / v)$, using an Ultra-Turrax T 10 homogenizer as described in [28,29]. In each experiment, the brain homogenates from 2 rats were aliquoted and incubated with $70 \mu \mathrm{M} \mathrm{H}_{2} \mathrm{O}_{2}$ in the absence or in the presence of $0.1 \mathrm{mM}$ isatin at $37^{\circ} \mathrm{C}$ for $30 \mathrm{~min}$. Control brain homogenates also prepared from 2 rats were incubated during the same period without oxidation in the presence or in the absence of added isatin.

The mild oxidation of GAPDH was performed as described in [54] by incubating GAPDH with $70 \mu \mathrm{M} \mathrm{H}_{2} \mathrm{O}_{2}$ for $30 \mathrm{~min}$ at $20^{\circ} \mathrm{C}$ in $50 \mathrm{mM}$ phosphate buffer, pH 7.4.

\subsection{Immobilization of Amyloid- $\beta$ Protein Fragment 1-42 on Affi-Gel 10}

Amyloid- $\beta$ protein fragment 1-42 (1 mg) dissolved in $250 \mu \mathrm{L}$ of distilled water was diluted with equal volume of $0.1 \mathrm{M} \mathrm{Na-acetate} \mathrm{buffer,} \mathrm{pH} 4.0$. In parallel, an Affi-Gel 10 resin $(0.5 \mathrm{~mL})$ was washed on a glass filter with 10 volumes of water and 2 volumes of the same buffer. The resin was transferred to the $1.5 \mathrm{~mL}$ Eppendorf tubes and the buffer was eliminated by aspiration after 
centrifugation of resin slurry at $4000 \mathrm{rpm}$ for 3 min using an Eppendorf centrifuge 5415R (Germany). Amyloid- $\beta$ protein fragment was added to the mixture $(1: 1)$ and incubated at $4{ }^{\circ} \mathrm{C}$ overnight at a gentle stirring. The unbound protein fragment was removed by repeated centrifugations (4-5 times) as above in $1 \mathrm{M}$ Tris-acetate buffer, $\mathrm{pH}$ 7.0. After addition of the same buffer the resultant suspension $(1: 1, v / v)$ was incubated at $4{ }^{\circ} \mathrm{C}$ for $4 \mathrm{~h}$ at a gentle stirring. After washing $4-5$ times and resuspending in $50 \mathrm{mM}$ potassium phosphate buffer, $\mathrm{pH} 7.4$, containing $0.02 \% \mathrm{NaN}_{3}$, the Affi-Gel 10 resin with the immobilized amyloid- $\beta$ protein fragment was stored at $4{ }^{\circ} \mathrm{C}$.

All the above-mentioned incubations were performed with the control Affi-Gel, except the addition of amyloid- $\beta$ protein fragment.

\subsection{Affinity Interactions}

After incubation at various conditions (see above) homogenates were lysed with 3\% Triton X-100 (final concentration) at $4{ }^{\circ} \mathrm{C}$ for $1 \mathrm{~h}$, diluted three-fold with $50 \mathrm{mM}$ potassium phosphate buffer, $\mathrm{pH} 7.4$, and centrifuged at $16,000 \mathrm{rpm}$ for $20 \mathrm{~min}$ at $4{ }^{\circ} \mathrm{C}$. The resultant supernatant $(5 \mathrm{mg}$ of protein $/ \mathrm{mL})$ was added to the suspension of the affinity sorbent (Affi-Gel 10 with the immobilized amyloid- $\beta$ protein) $(1: 1 v / v)$. Bacitracin, aprotinin, and PMSF were added up to the concentrations of $0.005 \%$, $0.01 \%$, and $1 \mathrm{mM}$, respectively, and the suspension was incubated overnight at $4{ }^{\circ} \mathrm{C}$ at a gentle stirring. Such incubation was previously used for the analysis of protein interactions with the recombinant cytoplasmic domain of amyloid- $\beta$ precursor protein [20]. The same incubations were also performed with the control Affi-Gel 10 without immobilized protein ligands.

After the incubation the sorbent was washed with the same potassium phosphate buffer up to the absence of the protein in the washing (evaluated by baseline at $\mathrm{D}_{280}$ ) and then packed into the columns $(1 \times 0.75 \mathrm{~mL})$. Proteins were eluted from the column by $1 \mathrm{M}$ glycine buffer, $\mathrm{pH} 2.8$, containing $150 \mathrm{mM}$ $\mathrm{NaCl}$ at a flow rate of $0.5 \mathrm{~mL} / \mathrm{min}$. The eluate was concentrated up to $0.200 \mathrm{~mL}$ using Amicon Ultra centrifugal filter devices (Millipore, Hessen, Germany) [29]. Proteins were extracted, modified, and digested on filters using the recently published FASP (filter-aided sample preparation) protocol [78].

The peptide samples were analyzed using Ultimate 3000 nano-flow HPLC (Thermo Scientific, Waltham, MA, USA) connected to a LTQ Orbitrap Elite (Thermo Scientific, Waltham, MA USA) mass spectrometer equipped with a Nanospray Flex NG ion source (Thermo Scientific, Waltham, MA USA). Peptide separation was carried out on a RP-HPLC column Zorbax 300SB-C18 (C18 particle size of $3.5 \mu \mathrm{m}$, inner diameter of $75 \mu \mathrm{m}$ and length of $150 \mathrm{~mm}$ ) using a linear gradient from $95 \%$ solvent A (water, $0.1 \%$ formic acid) and 5\% solvent B (water, $0.1 \%$ formic acid, and $80 \%$ acetonitrile) to $60 \%$ solvent B over $85 \mathrm{~min}$ at a flow rate of $0.3 \mu \mathrm{L} / \mathrm{min}$.

Mass spectra were acquired in the positive ion mode. Data was acquired in the Orbitrap analyzer (Thermo Scientific, Waltham, MA USA) with resolution of 60,000 ( $\mathrm{m} / \mathrm{z} 400)$ for MS and 15,000 $(m / z$ 400) for MS/MS scans.

Survey MS scan was followed by MS/MS spectra of the five most abundant precursors. For peptide fragmentation higher energy collisional dissociation (HCD) was used; the signal threshold was set to 10,000 for an isolation window of $2 \mathrm{~m} / \mathrm{z}$ and the first mass of HCD spectra was set to $100 \mathrm{~m} / \mathrm{z}$. The collision energy was set to $35 \mathrm{eV}$. Fragmented precursors were dynamically excluded from 
targeting for $60 \mathrm{~s}$. Singly charged ions and ions with undefined charge states were excluded from triggering MS/MS scans.

Protein identification was performed using MASCOT software (www.matrixscience.com). All tandem mass spectra were searched against the SwissProt database (release 2014_02, [79]) The following search parameters were used: Trypsin was used as the cutting enzyme, mass tolerance for the monoisotopic peptide window was set to $\pm 20 \mathrm{ppm}$, the MS/MS tolerance window was set to $\pm 0.05 \mathrm{Da}$ and one missed cleavage was allowed. Cysteine carbamidomethyl and oxidized methionine were chosen as variable modifications. The criteria of positive identification were set as following: Minimum score of 50, at least three positive identifications from three different runs.

\subsection{SPR (Surface Plasmon Resonance) Measurements}

GAPDH interaction with immobilized amyloid-beta and actin has been studied using an optical biosensor Biacore 3000 (GE Healthcare, Piscataway, NJ, USA) and the Biacore Control software (GE Healthcare) for instrument operation. All the experiments were performed with the standard optical chips Biacore CM5. Molecular interactions were registered as sensograms representing the records of biosensor signals in resonant units (RU) as time function. The interactions were estimated by subtracting the biosensor signal of a blank flow cell from the signal of the cell with the immobilized ligand or protein.

Covalent immobilization of the proteins (Figure 1) on the sensor chip included surface activation by the $0.2 \mathrm{M} \mathrm{EDC} / 0.05 \mathrm{M}$ NHS mixture and subsequent injection of the solutions $(100 \mu \mathrm{g} / \mathrm{mL})$ of actin or amyloid- $\beta$ in $10 \mathrm{mM}$ acetate buffer, $\mathrm{pH} 4.0$, at a flow rate of $5 \mu \mathrm{L} / \mathrm{min}$ for 10 and $30 \mathrm{~min}$, respectively. Washing and residual active group inactivations were performed as described in [29].

Protein-protein interactions were monitored by injecting at least five different concentrations of native or oxidized GAPDH $(1-10 \mu \mathrm{M})$ dissolved in $50 \mathrm{mM}$ potassium phosphate buffer, $\mathrm{pH} 7.4$ (running buffer), at a flow rate of $5 \mu \mathrm{L} / \mathrm{min}$ for $5 \mathrm{~min}$. Each experiment was repeated from three to five times using three different CM5 cuvettes with three different commercial preparations of immobilized amyloid- $\beta$ peptide. The sensor surface was regenerated after each measurement cycle by washing with $1 \mathrm{M} \mathrm{NaCl}$ in the running buffer and $50 \mathrm{mM}$ glycine, $\mathrm{pH} 9.5$, for $0.5 \mathrm{~min}$ at a flow rate of $50 \mu \mathrm{L} / \mathrm{min}$.

Data analysis was performed by applying "Biacore Evaluation v. 4.1" software. To determine the equilibrium dissociation constant $\left(K_{\mathrm{d}}=1 / K_{\mathrm{a}}\right)$ the equilibrium data were fitted to a single-site model (Equation (1)):

$$
R_{\mathrm{eq}}=\left(R_{\max } \cdot C \cdot K_{\mathrm{a}}\right) /\left(1+C \cdot K_{\mathrm{a}}\right)
$$

where $R_{\max }$ stands for the maximal response; $C$ is the concentration of a protein; $R_{\mathrm{eq}}$ is the equilibrium response at a given protein concentration; and $K_{\mathrm{a}}$ is the equilibrium association constant.

\subsection{Statistical Analysis}

Statistical significance of differences was evaluated by paired Student's $t$-test. Differences were considered as statistically significant at $p<0.05$. 


\section{Conclusions}

In this study we have investigated profiles of amyloid-binding proteins isolated from control rat brain homogenates and rat brain homogenates treated with hydrogen peroxide (oxidative stress simulation), the small non-peptide endogenous regulator isatin (indole-2,3-dione), and homogenates treated with hydrogen peroxide in the presence of isatin. Proteomic profiling of control rat brain homogenates resulted in identification of 89 individual intracellular amyloid-binding proteins and approximately $25 \%$ of them were previously identified as isatin-binding proteins. More than $30 \%$ of the amyloid-binding proteins are differentially expressed or altered/oxidatively modified in AD patients. Incubation of brain homogenates with $70 \mu \mathrm{M}$ hydrogen peroxide significantly influenced the profile of amyloid- $\beta$ binding proteins and $0.1 \mathrm{mM}$ isatin decreased the number of identified amyloid- $\beta$ binding proteins both in control and hydrogen peroxide treated brain homogenates. The effects of hydrogen peroxide and isatin have been confirmed in optical biosensor experiments with purified glyceraldehyde-3-phosphate dehydrogenase, one of the known amyloid- $\beta$ binding proteins also identified in this study. Our results suggest that isatin protects crucial intracellular protein targets against amyloid binding. This effect possibly favors intracellular degradation of this protein via preventing formation of amyloid- $\beta$ oligomers described in the literature for some isatin derivatives. If such a scenario occurs in vivo, it appears that endogenous and/or pharmacological compounds decreasing amyloid- $\beta$ interaction with numerous amyloid-binding proteins in the brain would be especially effective at early stages of $\mathrm{AD}$, when toxic amyloid- $\beta$ oligomers have not yet been formed.

\section{Supplementary Materials}

Supplementary tables can be found at http://www.mdpi.com/1422-0067/16/01/0476/s1.

\section{Acknowledgments}

This work was supported by the Russian Scientific Foundation grant \# 14-24-00100.

\section{Author Contributions}

Alexei E. Medvedev, Alexis S. Ivanov, and Alexander A. Makarov conceived the study and performed data analysis, Olga A. Buneeva performed affinity based isolation of amyloid-binding proteins and data analysis, Arthur T. Kopylov and Victor G. Zgoda performed mass spectrometry studies and protein identification and contributed with valuable discussion, Oksana V. Gnedenko performed optical biosensor measurements, Marina V. Medvedeva purified glyceraldehyde-3-phosphate dehydrogenase and studied the effect of hydrogen peroxide on catalytic activity of this enzyme. Sergey A. Kozin performed data analysis and contributed with valuable discussions. Alexei E. Medvedev drafted the manuscript. All authors read and approved the final manuscript.

\section{Conflicts of Interest}

The authors declare no conflict of interest. 


\section{References}

1. Schmechel, D.E.; Saunders, A.M.; Strittmatter, W.J.; Crain, B.J.; Hulette, C.M.; Joo, S.H.; Pericak-Vance, M.A.; Goldgaber, D.; Roses A.D. Increased amyloid beta-peptide deposition in cerebral cortex as a consequence of apolipoprotein E genotype in late-onset Alzheimer disease. Proc. Natl. Acad. Sci. USA 1993, 90, 9649-9653.

2. Saido, T.C.; Iwatsubo, T.; Mann, D.M.; Shimada, H.; Ihara, Y.; Kawashima, S. Dominant and differential deposition of distinct $\beta$-amyloid peptide species, $A \beta_{\mathrm{N} 3}(\mathrm{pE})$, in senile plaques. Neuron 1995, 14, 457-466.

3. Hardy, J.; Selkoe, D.J. The amyloid hypothesis of Alzheimer's disease: Progress and problems on the road to therapeutics. Science 2002, 297, 353-356.

4. LaFerla, F.M.; Green, K.N.; Oddo, S. Intracellular amyloid- $\beta$ in Alzheimer's disease. Nat. Rev. Neurosci. 2007, 8, 499-509.

5. Masters, C.L.; Selkoe, D.J. Biochemistry of amyloid $\beta$-protein and amyloid deposits in Alzheimer disease. Cold Spring Harb. Perspect. Med. 2012, 6, a006262.

6. Mitkevich, V.A.; Petrushanko, I.Y.; Yegorov, Y.E.; Simonenko, O.V.; Vishnyakova, K.S.; Kulikova, A.A.; Tsvetkov, P.O.; Makarov, A.A.; Kozin, S.A. Isomerization of Asp7 leads to increased toxic effect of amyloid- 342 on human neuronal cells. Cell Death Dis. 2013, 4, e939.

7. Kozin, S.A.; Cheglakov, I.B.; Ovsepyan, A.A.; Telegin, G.B.; Tsvetkov, P.O.; Lisitsa, A.V.; Makarov, A.A. Peripherally applied synthetic peptide isoAsp-A $\beta(\mathbf{1}-\mathbf{4 2})$ triggers cerebral $\beta$-amyloidosis. Neurotox. Res. 2013, 24, 370-376.

8. Upadhaya, A.; Kosterin, I.; Kumar, S.; von Arnim, C.A.; Yamaguchi, H.; Fändrich, M.; Walter, J.; Thal, D.R. Biochemical stages of amyloid- $\beta$ peptide aggregation and accumulation in the human brain and their association with symptomatic and pathologically preclinical Alzheimer's disease. Brain 2014, 137, 887-903.

9. Li, Q.X.; Maynard, C.; Cappai, R.; McLean, C.A.; Cherny, R.A.; Lynch T.; Culvenor, J.G.; Trevaskis, J.; Tanner, J.E.; Bailey, K.A.; et al. Intracellular accumulation of detergent-soluble amyloidogenic A $\beta$ fragment of Alzheimer's disease precursor protein in the hippocampus of aged transgenic mice. J. Neurochem. 1999, 72, 2479-2487.

10. Wirths, O.; Multhaup, G.; Czech, C.; Blanchard, V.; Moussaoui, S.; Tremp, G.; Pradier, L.; Beyreuther, K.; Bayer, T.A. Intraneuronal $A \beta$ accumulation precedes plaque formation in $\beta$-amyloid precursor protein and presenilin-1 double-transgenic mice. Neurosci. Lett. 2001, 306, 116-120.

11. Butterfield, D.A.; Sultana, R.; Poon, H.F. Redox proteomics: A new approach to investigate oxidative stress in Alzheimer's disease. In Redox Proteomics: From Protein Modifications to Cellular Dysfunction and Diseases; Dalle-Donne, I., Scaloni, A., Butterfield, D.A., Eds.; John Wiley \& Sons Inc.: Hoboken, NJ, USA, 2006; pp. 563-603.

12. Knobloch, M.; Konietzko, U.; Krebs, D.C.; Nitsch, R.M. Intracellular A $\beta$ and cognitive deficits precede $\beta$-amyloid deposition in transgenic arcA $\beta$ mice. Neurobiol. Aging 2007, 28, 1297-1306.

13. Reddy, P.H.; Beal M.F. Amyloid beta, mitochondrial dysfunction and synaptic damage: Implications for cognitive decline in aging and Alzheimer's disease. Trends Mol. Med. 2008, 14, 45-53. 
14. Spuch, C.; Ortolano, S.; Navarro, C. New insights in the amyloid-beta interaction with mitochondria. J. Aging Res. 2012, 324968.

15. Wu, Z.; Zhu, Y.; Cao, X.; Sun, S.; Zhao, B. Mitochondrial toxic effects of A $\beta$ through mitofusins in the early pathogenesis of Alzheimer's disease. Mol. Neurobiol. 2004, 50, 986-996.

16. Xu, G.; Stevens, S.M., Jr.; Moore, B.D.; McClung, S.; Borchelt, D.R. Cytosolic proteins lose solubility as amyloid deposits in a transgenic mouse model of Alzheimer-type amyloidosis. Hum. Mol. Genet. 2013, 22, 2765-2774.

17. Habib, L.; Lee, M.T.C.; Yang, J. Inhibitors of catalase-amyloid interactions protect cells from $\beta$-amyloid-induced oxidative stress and toxicity. J. Biol. Chem. 2010, 285, 38933-38943.

18. Hernandez-Zimbron, L.F.; Luna-Munoz, J.; Mena, R.; Vazquez-Ramirez, R.; Kubli-Garfias, C.; Cribbs, D.H.; Manoutcharian, K.; Gevorkian, G. Amyloid- $\beta$ peptide binds to cytochrome C oxidase subunit 1. PLoS One 2012, 7, e42344.

19. Calero, M.; Rostagno, A.; Ghiso, J. Search for amyloid-binding proteins by affinity chromatography. Methods Mol. Biol. 2012, 849, 213-223.

20. Schulze, H.; Schuler, A.; Stuber, D.; Dobeli, H.; Langen, H.; Huber, G. Rat brain glyceraldehyde-3-phosphate dehydrogenase interacts with the recombinant cytoplasmic domain of Alzheimer's beta-amyloid precursor protein. J. Neurochem. 1993, 60, 1915-1922.

21. Verdier, Y.; Földi, I.; Sergeant, N.; Fülöp, L.; Penke, Z.; Janáky, T.; Szücs, M.; Penke, B. Characterization of the interaction between A $\beta$ 1-42 and glyceraldehyde phosphodehydrogenase. J. Pept. Sci. 2008, 14, 755-762.

22. Naletova, I.; Schmalhausen, E.; Kharitonov, A.; Katrukha, A.; Saso, L.; Caprioli, A.; Muronetz, V. Non-native glyceraldehyde-3-phosphate dehydrogenase can be an intrinsic component of amyloid structures. Biochim. Biophys. Acta 2008, 1784, 2052-2058.

23. Butterfield, D.A.; Hardas, S.S.; Bader Lange, M.L. Oxidatively modified glyceraldehyde-3-phosphate dehydrogenase (GAPDH) and Alzheimer disease: Many pathways to neurodegeneration. J. Alzheimers Dis. 2010, 20, 369-393.

24. Medvedev, A.E., Clow, A.; Sandler, M.; Glover, V. Isatin-A link between natriuretic peptides and monoamines? Biochem. Pharmacol. 1996, 52, 385-391.

25. Medvedev, A.; Igosheva, N.; Crumeyrolle-Arias, M.; Glover, V. Isatin: Role in stress and anxiety. Stress 2005, 8, 175-183.

26. Medvedev, A.; Buneeva, O.; Gnedenko, O.; Fedchenko, V.; Medvedeva, M.; Ivanov, Y.; Glover, V.; Sandler, M. Isatin interaction with glyceraldehyde-3-phosphate dehydrogenase, a putative target for neuroprotective drugs: Partial agonism with deprenyl. J. Neural. Transm. Suppl. 2006, 71, 195-203.

27. Medvedev, A.; Buneeva, O.; Glover, V. Biological targets for isatin and its analogues: Implications for therapy. Biologics 2007, 1, 151-162.

28. Crumeyrolle-Arias, M.; Buneeva, O.; Zgoda, V.; Kopylov, A.; Cardona, A.; Tournaire, M.-C.; Pozdnev, V.; Glover, V.; Medvedev, A. Isatin binding proteins in rat brain: In situ imaging, quantitative characterization of specific $\left[{ }^{3} \mathrm{H}\right]$ isatin binding, and proteomic profiling. J. Neurosci. Res. 2009, 87, 2763-2772. 
29. Buneeva, O.; Gnedenko, O.; Zgoda, V.; Kopylov, A.; Glover, V.; Ivanov, A.; Medvedev, A.; Archakov, A. Isatin binding proteins of rat and mouse brain: Proteomic identification and optical biosensor validation. Proteomics 2010, 10, 23-37.

30. Buneeva, O.A.; Kopylov, A.T.; Tikhonova, O.V.; Zgoda, V.G.; Medvedev, A.E.; Archakov, A.I. Effect of affinity sorbent on proteomic profiling of isatin binding proteins of mouse brain. Biochemistry (Moscow) 2012, 77, 1326-1328.

31. Butterfield, D.A.; Poon, H.F.; St Clair, D.; Keller, J.N.; Pierce, W.M.; Klein, J.B.; Markesbery, W.R. Redox proteomics identification of oxidatively modified hippocampal proteins in mild cognitive impairment: Insights into the development of Alzheimer's disease. Neurobiol. Dis. 2006, 22, 223-232.

32. Baraibar, M.A.; Liu, L.; Ahmed, E.K.; Friguet, B. Protein oxidative damage at the crossroads of cellular senescence, aging, and age-related diseases. Oxid. Med. Cell. Longev. 2012, 2012, 919832.

33. Di Domenico, F.; Pupo, G.; Tramutola, A.; Giorgi, A.; Schininà, M.E.; Coccia, R.; Head, E.; Butterfield, D.A.; Perluigi, M. Redox proteomics analysis of HNE-modified proteins in Down syndrome brain: Clues for understanding the development of Alzheimer disease. Free Radic. Biol. Med. 2014, 71, 270-280.

34. Witzmann, F.A.; Arnold, R.J.; Bai, F.; Hrncirova, P.; Kimpel, M.W.; Mechref, Y.S.; McBride, W.J.; Novotny, M.V.; Pedrick, N.M.; Ringham, H.N.; et al. A proteomic survey of rat cerebral cortical synaptosomes. Proteomics 2005, 5, 2177-2201.

35. Reed, T.T.; Sultana, R.; Butterfield, D.A. Redox proteomics of oxidatively modified brain proteins in mild cognitive impairment. In Neuroproteomics; Alzate, O., Ed.; CRC Press: Boca Raton, FL, USA, 2010.

36. Butterfield, D.A. Amyloid $\beta$-peptide (1-42)-induced oxidative stress and neurotoxicity: Implications for neurodegeneration in Alzheimer's disease brain. A review. Free Radic. Res. 2002, 36, 1307-1313.

37. Butterfield, D.A. Proteomics: A new approach to investigate oxidative stress in Alzheimer's disease brain. Brain Res. 2004, 1000, 1-7.

38. Castegna, A.; Aksenov, M.; Thongboonkerd, V.; Klein, J.B.; Pierce, W.M.; Booze, R.; Markesbery, W.R.; Butterfield, D.A. Proteomic identification of oxidatively modified proteins in Alzheimer's disease brain. Part II: Dihydropyrimidinase-related protein 2, $\alpha$-enolase andheat shock cognate 71. J. Neurochem. 2002, 82, 1524-1532.

39. Tsuji, T.; Shiozaki, A.; Kohno, R.; Yoshizato, K.; Shimohama, S. Proteomic profiling and neurodegeneration in Alzheimer's disease. Neurochem. Res. 2002, 27, 1245-1253.

40. Castegna, A.; Aksenov, M.; Aksenova, M.; Thongboonkerd, V.; Klein, J.B.; Pierce, W.M.; Booze, R.; Markesbery, W.R.; Butterfield, D.A. Proteomic identification of oxidatively modified proteins in Alzheimer's disease brain. Part I: Creatine kinase BB, glutamine synthase, and ubiquitin carboxyterminal hydrolase L-1. Free Radic. Biol. Med. 2002, 33, 562-571.

41. Butterfield, D.A.; Owen, J.B. Lectin-affinity chromatography brain glycoproteomics and Alzheimer's disease: Insights into protein alterations consistent with the pathology and progression of this dementing disorder. Proteomics Clin. Appl. 2011, 5, 50-56. 
42. Lubec, G.; Nonaka, M.; Krapfenbauer, K.; Gratzer, M.; Cairns, N.; Fountoulakis, M. Expression of the dihydropyrimidinase related protein 2 (DRP-2) in Down syndrome and Alzheimer's disease brain is downregulated at the mRNA and dysregulated at the protein level. J. Neural. Transm. Suppl. 1999, 57, 161-177.

43. Krapfenbauer, K.; Engidawork, E.; Cairns, N.; Fountoulakis, M.; Lubec, G. Aberrant expression of peroxiredoxin subtypes in neurodegenerative disorders. Brain Res. 2003, 967, 152-160.

44. Yoo, B.C.; Cairns, N.; Fountoulakis, M.; Lubec, G. Synaptosomal proteins, beta-soluble $N$-ethylmaleimidesensitive factor attachment protein ( $\beta$-SNAP), $\gamma$-SNAP and synaptotagmin I in brain of patients with Down syndrome and Alzheimer's disease. Dement. Geriatr. Cogn. Disord. 2001, 12, 219-225.

45. Yoo, B.C.; Kim, S.H.; Cairns, N.; Fountoulakis, M.; Lubec, G. Deranged expression of molecular chaperones in brains of patients with Alzheimer's disease. Biochem. Biophys. Res. Commun. 2001, 280, 249-258.

46. Yoo, B.C.; Vlkolinsky, R.; Engidawork, E.; Cairns, N.; Fountoulakis, M.; Lubec, G. Differential expression of molecular chaperones in brain of patients with Down syndrome. Electrophoresis 2001, 22, 1233-1241.

47. Puchades, M.; Hansson, S.F.; Nilsson, C.L.; Andreasen, N.; Blennow, K.; Davidsson, P. Proteomic studies of potential cerebrospinal fluid protein markers for Alzheimer's disease. Mol. Brain Res. 2003, 118, 140-146.

48. Kim, S.H.; Fountoulakis, M.; Cairns, N.; Lubec, G. Protein levels of human peroxiredoxin subtypes in brains of patients with Alzheimer's disease and Down syndrome. J. Neural. Transm. Suppl. 2001, $61,223-235$.

49. Liao, L.; Cheng, D.; Wang, J.; Duong, D.M.; Losik, T.G.; Gearing, M.; Rees, H.D.; Lah, J.J.; Levey, A.I.; Peng, J. Proteomic characterization of postmortem amyloid plaques isolated by laser capture microdissection. J. Biol. Chem. 2004, 279, 37061-37068.

50. Chang, R.Y.K.; Etheridge, N.; Dodd, P.R.; Nouwens, A.S. Targeted quantitative analysis of synaptic proteins in Alzheimer's disease brain. Neurochem. Int. 2014, 75, 66-75.

51. Andreev, V.P.; Petyuk, V.A.; Brewer, H.M.; Karpievitch, Y.V.; Xie, F.; Clarke, J.; Camp, D.; Smith, R.D.; Lieberman, A.P.; Albin, R.L.; et al. Label-free quantitative LC-MS proteomics of Alzheimer's disease and normally aged human brains. J. Proteome Res. 2012, 11, 3053-3067.

52. Chen, S.; Lu, F.F., Seeman, P.; Liu, F. Quantitative proteomic analysis of human substantia nigra in Alzheimer's disease, Huntington's disease and multiple sclerosis. Neurochem. Res. 2012, 37, 2805-2813.

53. Zahid, S.; Khan, R.; Oellerich, M.; Ahmed, N.; Asif, A.R. Differential S-nitrosylation of proteins in Alzheimer's disease. Neuroscience 2013, 256C, 126-136.

54. Schmalhausen, E.V.; Nagradova, N.K.; Boschi-Muller, S.; Branlant, G.; Muronetz, V.I. Mildly oxidized GAPDH: The coupling of the dehydrogenase and acyl phosphatase activities. FEBS Lett. 1999, 452, 219-222.

55. Sunaga, K.; Takahashi, H.; Chuang, D.M.; Ishitani, R. Glyceraldehyde-3-phosphate dehydrogenase is over-expressed during apoptotic death of neuronal cultures and is recognized by a monoclonal antibody against amyloid plaques from Alzheimer's brain. Neurosci. Lett. 1995, 200, 133-136. 
56. Tamaoka, A.; Endoh, R.; Shoji, S.; Takahashi, H.; Hirokawa, K.; Teplow, D.B.; Selkoe, D.J.; Mori, H. Antibodies to amyloid beta protein $(A \beta)$ crossreact with glyceraldehyde-3-phosphate dehydrogenase (GAPDH). Neurobiol. Aging 1996, 17, 405-414.

57. Chuang, D.M.; Hough, C.; Senatorov, V.V. Glyceraldehyde-3-phosphate dehydrogenase, apoptosis, and neurodegenerative diseases. Annu. Rev. Pharmacol. Toxicol. 2005, 45, 269-290.

58. Cumming, R.C.; Schubert, D. Amyloid-beta induces disulfide bonding and aggregation of GAPDH in Alzheimer's disease. FASEB J. 2005, 19, 2060-2062.

59. Ishitani, R.; Tajima, H.; Takata, H.; Tsuchiya, K.; Kuwae, T.; Yamada, M.; Takahashi, H.; Tatton, N.A., Katsube, N. Proapoptotic protein glyceraldehyde-3-phosphate dehydrogenase: A possible site of action of antiapoptotic drugs. Prog. Neuropsychopharmacol. Biol. Psychiatry 2003, 27, 291-301.

60. Tatton, W.; Chalmers-Redman, R.; Tatton, N. Neuroprotection by deprenyl and other propargylamines: Glyceraldehyde-3-phosphate dehydrogenase rather than monoamine oxidase B. J. Neural Transm. 2003, 110, 509-515.

61. Schmitz, H.D.; Bereiter-Hahn, J. Glyceraldehyde-3-phosphate dehydrogenase associates with actin filaments in serum deprived NIH 3 T3 cells only. Cell Biol. Int. 2002, 26, 155-164.

62. Waingeh, V.F.; Gustafson, C.D.; Kozliak, E.I.; Lowe, S.L.; Knull, H.R.; Thomasson, K.A. Glycolytic enzyme interactions with yeast and skeletal muscle F-actin. Biophys. J. 2006, 90, 1371-1384.

63. Oyama, R.; Yamamoto, H.; Titani, K. Glutamine synthetase, hemoglobin alphachain, and macrophage migration inhibitory factor binding to amyloid $\beta$-protein: Their identification in rat brain by a novel affinity chromatography and in Alzheimer's disease brain by immunoprecipitation. Biochim. Biophys. Acta 2000, 1479, 91-102.

64. Mawatari, K.; Segawa, M.; Masatsuka, R.; Hanawa, Y.; Iinuma, F.; Watanabe, M. Fluorimetric determination of isatin in human urine and serum by liquid chromatography postcolumn photoirradiation. Analyst 2001, 126, 33-36.

65. Igosheva, N.; Matta, S.; Glover, V. Effect of acute stress and gender on isatin in rat tissues and serum. Physiol. Behav. 2004, 80, 665-668.

66. Panova, N.G.; Zemskova, M.A.; Axenova, L.N.; Medvedev, A.E. Does isatin interact with rat brain monoamine oxidases in vivo? Neurosci. Lett. 1997, 233, 58-60.

67. Pandeya, S.N.; Smitha, S.; Jyoti, M.; Sridhar, S.K. Biological activities of isatin and its derivatives. Acta Pharm. 2005, 55, 27-46.

68. Zhou, Y.; Zhao, Z.Q.; Xie, J.X. Effects of isatin on rotational behavior and DA levels in caudate putamen in Parkinsonian rats. Brain Res. 2001, 917, 127-132.

69. Hamaue, N.; Minami, M.; Terado, M.; Hirafuji, M.; Endo, T.; Machida, M.; Hiroshige, T.; Ogata, A.; Tashiro, K.; Saito, H.; et al. Comparative study of the effects of isatin, an endogenous MAO-inhibitor, and selegiline on bradykinesia and dopamine levels in a rat model of Parkinson's disease induced by the Japanese encephalitis virus. Neurotoxicology 2004, 25, 205-213.

70. Crumeyrolle-Arias, M.; Medvedev, A.; Cardona, A.; Barritault, D.; Glover, V. In situ imaging of specific binding of $\left[{ }^{3} \mathrm{H}\right]$ isatin in rat brain. J. Neurochem. 2003, 84, 618-620.

71. Medvedev, A.; Crumeyrolle-Arias, M.; Cardona, A.; Sandler, M.; Glover, V. Natriuretic peptide interaction with $\left[{ }^{3} \mathrm{H}\right]$ isatin binding sites in rat brain. Brain Res. 2005, 1042, 119-124. 
72. Medvedev, A.E.; Goodwin, D.L.; Sandler, M.; Glover, V. Efficacy of isatin analogues as antagonists of rat brain and heart atrial natriuretic peptide receptors coupled to particulate guanylate cyclase. Biochem. Pharmacol. 1999, 57, 913-915.

73. Nepali, K.; Sharma, S.; Sharma, M.; Bedi, P.M.S.; Dhar, K.L. Rational approaches, design strategies, structure activity relationship and mechanistic insights for anticancer hybrids. Eur. J. Med. Chem. 2014, 77, 422-487.

74. Campagna, F.; Catto, M.; Purgatorio, R.; Altomare, C.D.; Carotti, A.; de Stradis, A.; Palazzo, G. Synthesis and biophysical evaluation of arylhydrazono- $1 H$-2-indolinones as $\beta$-amyloid aggregation inhibitors. Eur. J. Med. Chem. 2011, 46, 275-284.

75. Gonzalez, A.; Quirante, J.; Nieto, J.; Almeida, M.R.; Saraiva, M.J.; Planas, A.; Arsequell, G.; Valencia, G. Isatin derivatives, a novel class of transthyretin fibrillogenesis inhibitors. Bioorg. Med. Chem. Lett. 2009, 19, 5270-5273.

76. Zala, D.; Hinckelmann, M.V.; Yu, H.; Lyra da Cunha, M.M.; Liot, G.; Cordelieres, F.P.; Marco, S.; Saudou, F. Vesicular glycolysis provides on-board energy for fast axonal transport. Cell 2013, 153, 479-491.

77. Scopes, R.K.; Stoter, A. Purification of all glycolytic enzymes from one muscle extract. Methods Enzymol. 1982, 90, 479-490.

78. Wisniewski, J.; Zougman, A.; Nagaraj, N.; Mann, M. Universal sample preparation method for proteome analysis. Nat. Methods 2009, 6, 359-362.

79. SwissProt database. Available online: ftp://ftp.uniprot.org/pub/databases/uniprot/current_release/ knowledgebase/complete/uniprot_sprot.fasta.gz (accessed on 24 December 2014).

(C) 2014 by the authors; licensee MDPI, Basel, Switzerland. This article is an open access article distributed under the terms and conditions of the Creative Commons Attribution license (http://creativecommons.org/licenses/by/4.0/). 